\title{
EKSPLORASI POSE DALAM PEMOTRETAN MODEL MELALUI KAJIAN VISUAL RELIEF KARMAWIBHANGGA
}

\author{
Noor Latif CM \\ Creative Advertising, School of Design, BINUS University \\ Jln. K.H. Syahdan 9, Kemanggisan, Palmerah, Jakarta Barat 11480 \\ lateevhaq@gmail.com
}

\begin{abstract}
Karmawibhangga Relief panel located at the foot of Borobudur is a relic of the visual artifacts that contains fragments of past life with a very high historical value. 160 Karmawibhangga panels tell the reality of people's lives at the time wrapped with a moral message plight. The relief provides a lot of visual references to be excavated and reconstructed again for the benefit of the creative industries today. This research digged one small part of the masterpieces of the past through photography. Understanding visual artists who create these reliefs will be beauty in the show gestures in building a very interesting story to be re-examined. Visual communication through gestures in relief Karmawibhangga enables new assumptions about body language dialect differences to current conditions. Through model genre photography, it is very useful in connection with the development of local nuanced scientific photography. Efforts to develop the traditions and culture through new media are expected to be creative commodity with a very strong product differentiation.
\end{abstract}

Keywords: photography, pose, relief, Karmawibhangga

\begin{abstract}
ABSTRAK
Panel Relief Karmawibhangga yang terletak di kaki candi Borobudur merupakan peninggalan artefak visual yang berisi fragmen kehidupan masa lalu dengan nilai sejarah yang sangat tinggi. 160 buah panel Karmawibhangga menceritakan realitas kehidupan masyarakat pada waktu itu yang dibalut dengan pesan moral lika-liku kehidupan. Relief tersebut memberikan banyak sekali referensi visual untuk dapat digali dan direkontruksi ulang untuk kepentingan industri kreatif saat ini. Penelitian ini menggali salah satu bagian kecil dari mahakarya masa lalu melalui media fotografi. Pemahaman visual seniman yang membuat relief tersebut akan keindahan dalam menampilkan gerak tubuh dalam membangun cerita sangat menarik untuk dikaji ulang. Komunikasi visual melalui gerak tubuh dalam relief Karmawibhangga tersebut memungkinkan asumsi baru tentang perbedaan dialek bahasa tubuh dengan kondisi sekarang. Melalui fotografi yang bergenre model hal tersebut sangat bermanfaat dalam kaitannya dengan pengembangan keilmuan fotografi yang bernuansa lokal. Upaya untuk mengembangkan tradisi dan budaya melalui media baru diharapkan dapat menjadi komoditi kreatif dengan diferensiasi produk yang sangat kuat.
\end{abstract}

Kata kunci: fotografi, pose, relief, Karmawibhangga 


\section{PENDAHULUAN}

Fotografi fesyen adalah genre fotografi yang yang lahir pada awal abad ke-20an, lahir bersamaan dengan berdirinya majalah fesyen ternama yaitu Vogue (Hacking, 2012). Berbicara masalah fotografi, genre fesyen banyak diminati oleh banyak anak muda yang memimpikan dirinya menjadi seorang fotografer ternama. Hingar-bingar kehidupan fotografi fesyen tidak dapat dielakkan dengan model-model cantik yang memukau (sebagai contoh Gambar 1).

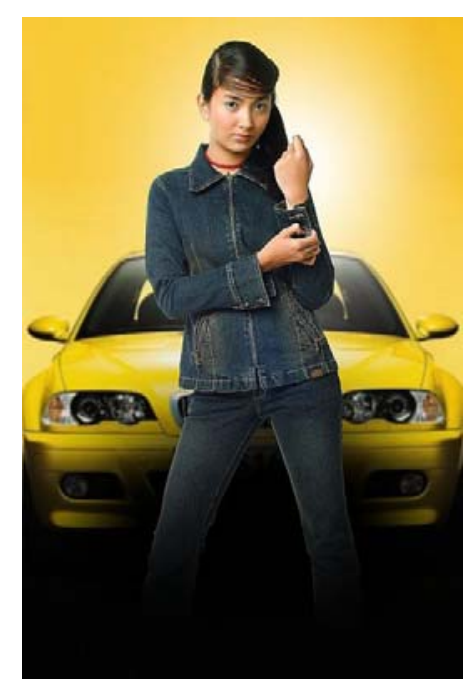

Gambar 1 Iklan AKO Jeans

(Sumber: Koleksi pribadi)

Kehidupan fotografer fesyen yang akrab dengan kehidupan selebriti papan atas tidak bisa dipungkiri menjadi magnet kuat bagi calon fotografer muda. Dalam skala lebih kecil, bagi kalangan penghobi fotografi, aktivitas yang berkaitan dengan pemotretan seorang model sangatlah tidak asing. Banyak acara "Hunting Model" digelar melalui jejaring sosial. Komunitas yang mewadahinya bagi fotografer pemula seakan akrab dengan pemotretan model.

Acara pemotretan model yang sekadar iseng semata hingga acara yang bersifat serius menawarkan konsep dan tema tertentu di dalam acaranya. Memotret model serasa mudah dan gampang untuk dilakukan. Euphoria semacam ini sangat memacu pergerakan penjualan kamera yang cukup tajam. Hal ini ditandai dengan maraknya inovasi untuk menghadirkan berbagai tipe dari merekmerek besar pabrikan kamera.

Terkadang secara tidak sadar kita sangat jenuh dengan hadirnya foto-foto yang bergenre fotografi model dengan pola kreativitas visual yang tidak jauh berbeda antara karya satu dengan lainnya. Saatnya yang tepat untuk memberikan alternatif kepada masyarakat fotografi model ataupun fesyen dengan konsep kreativitas yang bernuansa lokal dengan berbekal riset visual yang lazim digunakan oleh para fotografer secara sederhana (Prayanto, 2007). Peran yang seperti ini menjadi perhatian lingkungan institusi pendidikan kreatif karena sumbangsih kalangan akademik untuk dapat memberikan solusi kreatif atas kondisi semacam ini sangat dinantikan.

Wacana penggalian kreativitas melalui apa yang dimiliki namun terlupakan merupakan agenda yang patut digalakkan untuk menjaga kelestarian kekayaan tradisi dan budaya masa lampau, sehingga terjadi penguatan budaya di masyarakat (Sachari, 2007). Banyak sekali konten kreatif yang 
terdapat di dalam kekayaan peninggalan tradisi dan budaya tersebut. Kepiawaian untuk mengemas, menjadikan produk kreatif yang layak untuk disajikan dalam wacana dan kecenderungan masa kini, patut menjadi perhatian serius. Sebagai contoh adalah kekayaan artefak yang melekat pada candi Borobudur tidak akan habis untuk digali daya manfaat kreatifnya.

Borobudur adalah peninggalan arsitektural yang kaya dengan informasi visual masa lalu, ditandai dengan banyaknya periset yang telah melakukannya (Kandahjaya, 1995). Borobur sebagai tempat keagamaan umat budha dibangun awal abad ke-9 oleh seorang raja wangsa Syailendra, yaitu Sri Maharaja Samarotungga. Relief yang mengitarinya adalah salah satu relief yang mengisahkan Budha Gautama terpanjang di dunia. Kekayaan visual yang dimiliki borobudur masih sangat sedikit yang dimanfaatkan untuk menggerakkan komoditi kreatif, sementara ikon borobudur cukup kuat di mata masyarakat dunia. Hal ini ditandai dengan ditetapkannya bangunan cantik ini oleh UNESCO sebagai warisan budaya dunia (Leber, 2011). Seharusnya, apa pun yang diciptakan, apabila berkenaan dengan Borobudur, tentunya mudah untuk diterima sebagai produk komoditas global. Daya pikat Borobudur yang kuat selalu mampu menarik wisatawan lokal maupun asing untuk mengunjunginya.

Cerita di dalam relief Karmawibhangga (Gambar 2) masih menimbulkan spekulasi dari masyarakat terhadap keberadaannya. Relief tersebut hanyalah fondasi dari sebuah bangunan besar Borobudur. Atau, ia terkubur karena fragmen visualnya beradegan tidak senonoh. Bahkan masih banyak lagi versi untuk menjelaskan keberadaan relief Karmawibhangga tersebut.

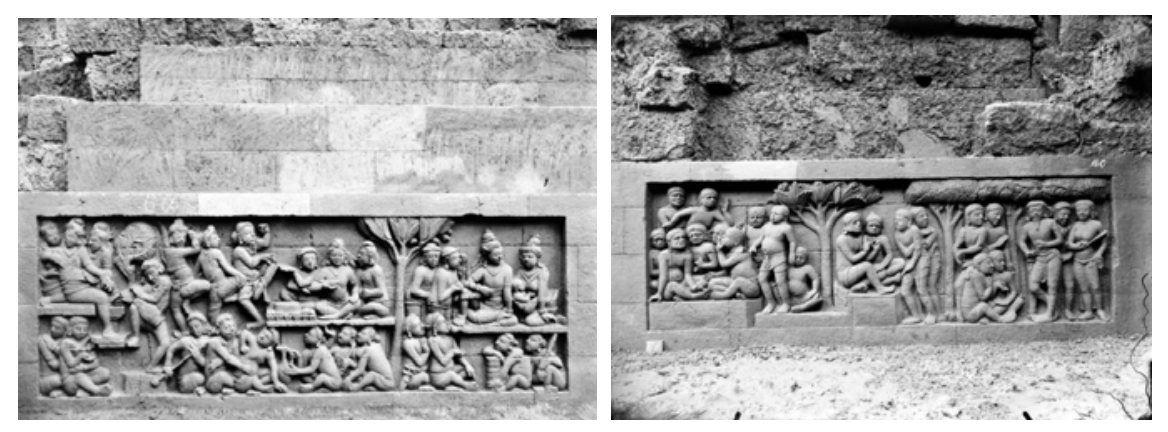

Gambar 2 Panel Relief Karmawibhangga No. 20 dan 21

(Sumber: www.luk.staff.ugm.ac.id)

Sampai saat ini relief tersebut tidak dipertontonkan secara langsung kepada pengunjung candi. Pengunjung hanya dapat menikmati susunan cerita relief tersebut melalui reproduksi foto yang ada di museum Borobudur, masih satu komplek dengan candi berada. Foto-foto hitam putih relief tersebut dihasilkan oleh fotografer pribumi pertama bernama Kasian Cheepas, yang dilakukannya selama proyek pemugaran oleh kerajaan Belanda. Kisah karma kehidupan yang digelar di dalam cerita relief Karmawibhangga seakan menggambarkan kondisi visual masyarakat pada waktu itu. Kreativitas sang pemahat relief Karmawibhangga patut diacungi jempol karena piawai menyusun narasi visual yang syarat dengan kandungan pesan spiritual (Kandahjaya, 1995).

Apakah gerakan adegan dalam relief Karmawibhangga, dapat diaplikasikan ke dalam fotografi model atau fesyen dalam bentuk pose. Untuk memperjelas proses penggunaan data visual dalam melakukan upaya rekonstruksi visual terhadap panel relief Karmawibhangga, ada beberapa poin yang akan disampaikan. Pertama, tidak semua panel relief Karmawibhangga dijadikan bahan acuan data. Mungkin ada relief yang cuma diambil bagian kecilnya saja. Kedua, penelitian hanya membahas gerakan secara visual tanpa menyertakan bahasan lain di dalamnya. Ketiga, output penelitian berupa analisis yang mengacu pada proses pemotretan yang telah ditentukan saja. 
Kehadiran objek penelitian berupa artefak warisan budaya yang sangat tinggi dapat memperkaya khazanah keilmuan fotografi pada khususnya dan kreatif pada umumnya. Tanpa kepedulian, fotografi kreatif Indonesia tidak akan mampu muncul dengan kebaruan platform estetika nusantara dan karakter yang kuat. Penelitian ini memberikan rangsangan kepada masyarakat dan kaum akademisi untuk peduli mendaur ulang peninggalan kejayaan masa lampau yang terpendam. Hasil yang diperoleh dari penelitian ini diharapkan memiliki manfaat yang sangat berarti, yaitu sebagai berikut. Pertama, secara pribadi dapat memberikan semangat untuk tetap konsisten mengembangkan budaya dan tradisi lokal dengan platform baru di ranah fotografi. Kedua, secara akademik dapat memberikan masukan dalam bentuk pengkayaan materi yang berhubungan dengan alternatif penggunaan pose dengan muatan lokal di ranah keilmuan fotografi. Ketiga, secara umum ikut berpartisipasi untuk mengangkat budaya dan tradisi lokal keruang publik yang lebih luas.

\section{METODE}

Penelitian ini dilakukan secara kualitatif. Rekonstruksi visual yang dilakukan terhadap panel relief Karmawibhangga melalui proses tafsir visual sangat subjektif dalam menentukan kaidah artistik di dalamnya. Faktor personal tidak mungkin ditanggalkan ketika respons artistik muncul. Kualitas peneliti dipertaruhkan untuk dapat menggali keunikan bahasa tubuh yang terdapat di dalam fragmen Karmawibhangga. Metode dalam penelitian ini tergambar dalam diagram berikut.

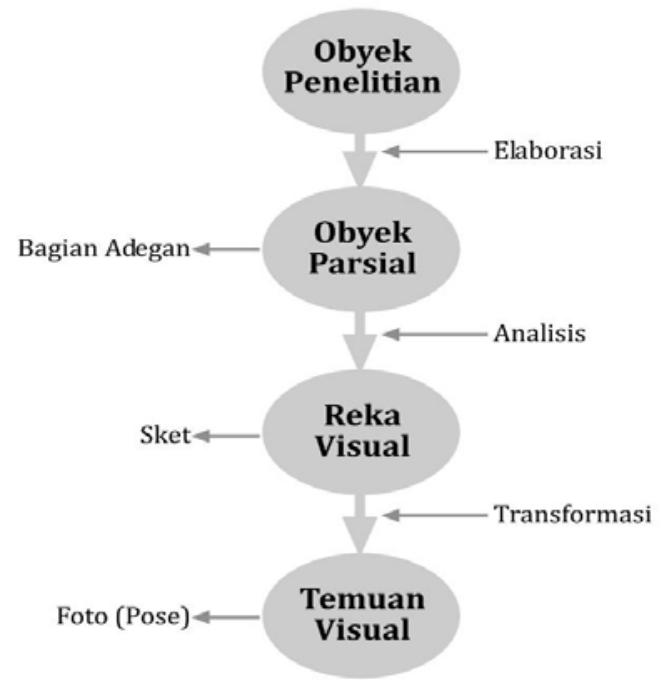

Gambar 3 Diagram Metode penelitian

Subjek utama penelitian adalah foto relief Karmawibhangga. Foto diambil dari koleksi wikipedia online yang bekerja sama dengan Tropen Museum Belanda. Keseluruhan data visual panel relief Karmawibhangga berjumlah 160 foto hasil karya fotografer Indonesia, yaitu Kassian Chepas tahun 1890. Relief Karmawibhangga hingga saat ini tertutup di dasar candi Borobudhur, sehingga data fisik secara langsung tidak bisa didapatkan. Selama ini karya foto Kassian Chepas cukup populer menjadi referensi visual tentang relief ini. Sebagai data pendamping adalah cuplikan foto panel relief Latitavistara berjumlah 120, diambil dari Leber (2011). Relief Latitavistara menceritakan perjalanan hidup Sang Budha, mulai dari proses sebelum lahir hingga menjadi Bodhisatwa. Selain relief Latitavistara, digunakan juga beberapa pose dalam iklan fesyen. 
Keseluruhan panel relief Karmawibhangga yang berjumlah 160 buah tidak semuanya mengandung materi gambar yang dibutuhkan dari penelitian ini. Kualifikasi kebutuhan data gambar yang diperlukan adalah (a) gambar yang diambil adalah pose perempuan, sesuai kebutuhan penelitian ini yang menitikberatkan kebutuhan pose untuk iklan fesyen atau pemotretan model perempuan; (b) pose yang ada harus utuh, untuk mempermudah penggalian dan pengkajian. Setelah evaluasi dilakukan, terpilih 66 buah panel relief Karmawibhangga yang sesuai dengan kebutuhan data visual. Gambar 4 merupakan contoh panel relief Karmawibhangga yang terpilih.
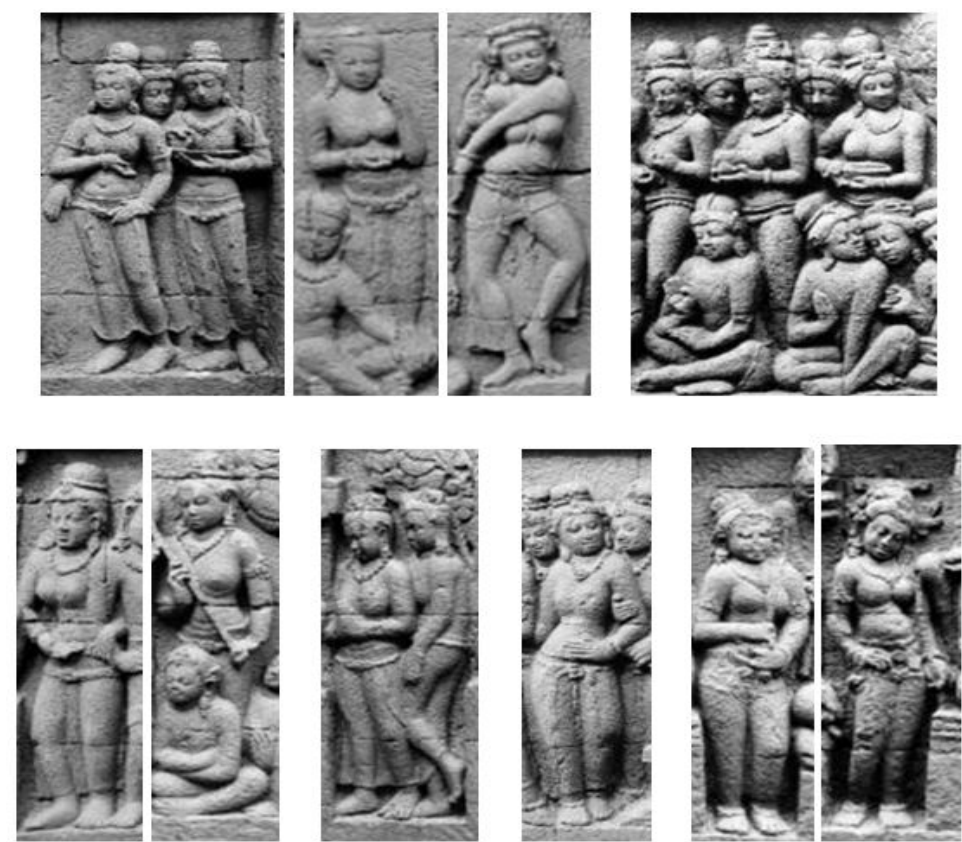

Gambar 4 Contoh Panel Relief Terpilih

(Sumber: www.luk.staff.ugm.ac.id)

Sementara itu, data visual pendukung yang diambil dari cuplikan gambar panel relief Latitavistara menjadi pembanding saja (Gambar 5). Cuplikan gambar panel relief yang berjumlah 120 buah tidak ditampilkan secara keseluruhan.

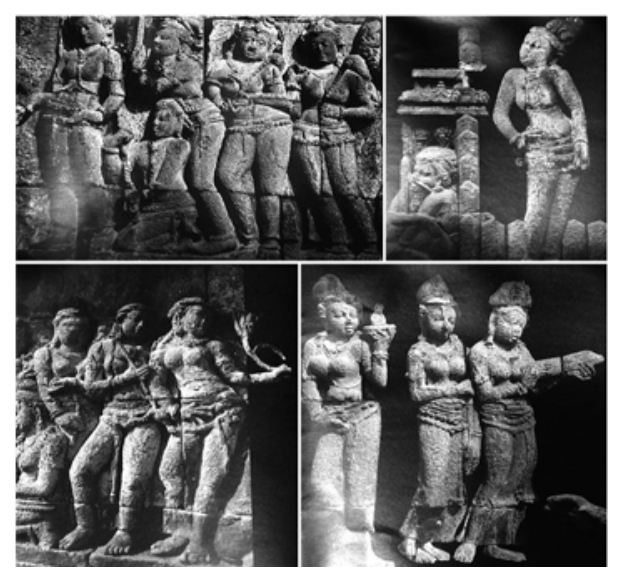

Gambar 5 Cuplikan Panel Relief Laltitavistara (Sumber: Leber, 2011) 
Lebih lanjut, titik berat penelitian lebih kepada kemungkinan untuk mengeksplorasi kandungan pose yang terdapat di dalam panel relief Karmawibhangga, bukan pada kajian pose dalam iklan fesyen komersial yang sudah ada. Mengingat dari itu semua, data visual iklan yang dibutuhkan tidak mengacu kepada kuantitas, tetapi lebih kepada contoh yang mewakili beberapa pose yang lazim digunakan. Data visual iklan yang ada ini berfungsi untuk mempertegas aplikasi pose dalam pemotretan model komersial untuk iklan, khususnya fesyen seperti pada Gambar 6.
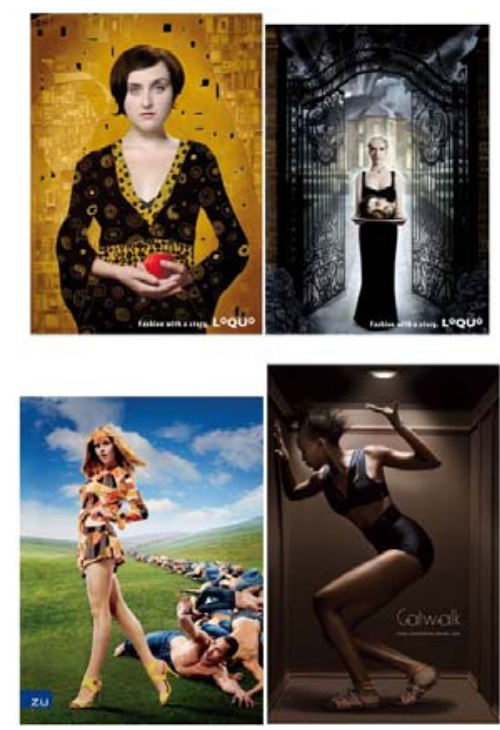

Gambar 6 Iklan Fesyen

(Sumber: www.adsoftheworld.com)

\section{HASIL DAN PEMBAHASAN}

Data visual yang terkumpul dari relief Karmawibhangga dapat dikelompokkan berdasarkan jenis pose yang ada, yaitu kaku, atraktif, dan gemulai. Dalam pose statik (kaku), gerakan pada gambar wanita yang ada hampir tidak memanfaatkan semua titik gerak yang ada sesuai dalam pembahasan teori tentang pose. Dibandingkan dengan pose yang lain, pose atraktif paling sedikit dijumpai pada keseluruhan data karena terjadi pada penggunaan adegan yang sangat khusus, yaitu tari-tarian. Kasus pose yang atraktif dapat disimpulkan dari maksimalnya penggunaan titik gerak untuk membentuk pose atau gerakan. Sementara itu, pose gemulai memanfaatkan semua titik gerak namun penggunaannya tidak terlalu berlebihan seperti pada kategori atraktif. Pose yang ditemui dan dikategorikan sebagai pose gemulai jumlahnya paling banyak pada data visual dalam penelitian ini. Titik gerak dalam pose dapat dilihat pada Gambar 7. 


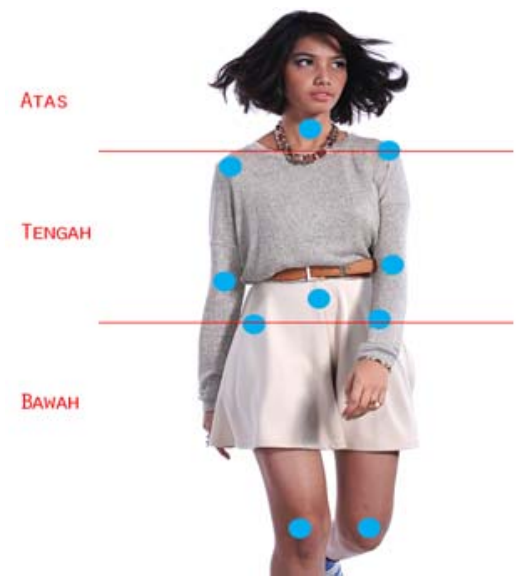

Gambar 7 Titik Gerak dalam Pose

(Sumber: dokumentasi pribadi)

Data pendukung cuplikan panel relief Latitavistara kurang lebih memiliki karakteristik yang sama dengan panel relief Karmawibhangga. Aplikasi pose dari yang kaku hingga gemulai ternyata dapat dijumpai pada data visual contoh iklan fesyen di atas.

Selama proses penelitian ada hal menarik yang merupakan temuan antara keterkaitan teori yang sering digunakan dalam pemotretan model dengan penyusunan gerakan untuk membentuk adegan dalam panel relief Karmawibangga. Akhir dari proses penelitian ini bermuara pada aplikasi pengembangan permasalahan tersebut. Aplikasi tersebut akan disusun menjadi dua tahap, yang nantinya menjadi pembuktian terhadap kandungan pose yang terdapat dalam relief Karmawibhangga.

Adapun proses tersebut adalah sebagai berikut. Salah satu bagian dari relief Karmawibangga khususnya pada panel ke-159 menjadi contoh kasus dalam proses akhir penelitian ini. Pose pada panel ke-159 merupakan jenis pose gemulai yang mewakili secara dominan dari keseluruhan pose yang terdapat dalam panel relief Karmawibhangga. Cuplikan gambar terpilih dipetakan alur gerakan dari masing-masing titik gerak dengan menggunakan garis merah. Terlihat jelas gerakan pada setiap titik gerak yang ditandai dengan tingkat kemiringan garis merah tersebut. Setelah itu dilakukan pemetaan gerak tubuh horizontal yang sering disebut dengan gesture, pada Gambar 8 dibawah ketiga ditandai dengan garis kuning (horizontal—red.).

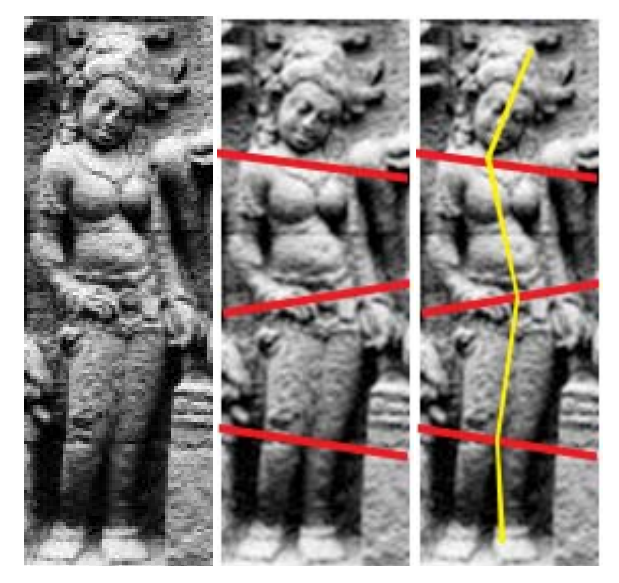

Gambar 8 Proses Reka Visual

(Sumber: www.wikipedia.com) 
Hasil dari pemetaan pada proses reka visual diaplikasikan ke dalam pemotretan sebenarnya. Reka visual di atas menjadi acuan dalam mengarahkan model selama proses pemotretan. Sedikit perubahan dalam kemiringan titik gerak (dengan catatan tidak meleset jauh dari acuan) akan menghasilkan variasi pose yang bervariatif. Lima foto berikut ini merupakan hasil dari reka visual di atas.

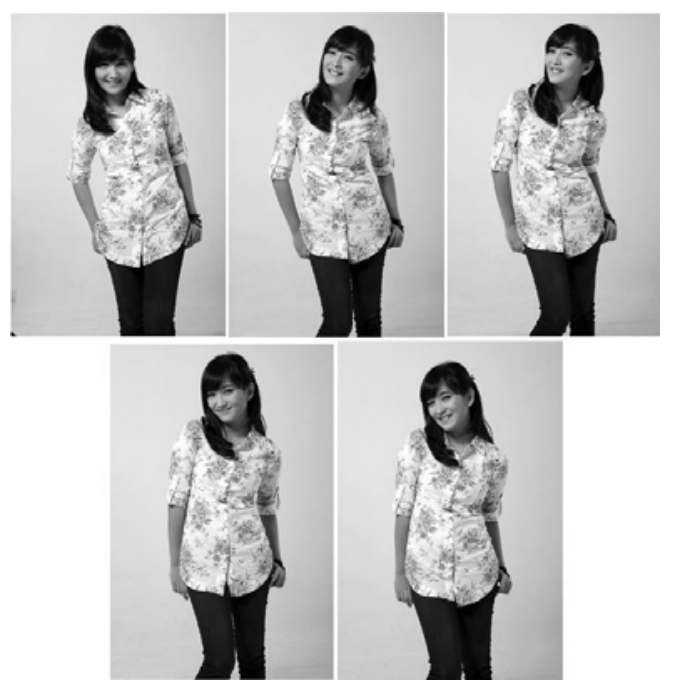

Gambar 9 Pose 5

(Sumber: dokumentasi pribadi)

\section{SIMPULAN}

Nenek moyang di abad ke-9, ketika menyusun adegan pada panel relief Candi Borobudur, sudah sadar dalam menggali pose sebagai penunjang adegan visual. Semua gerakan yang muncul tidak tampak nyata seperti memotret aktivitas harian. Eksplorasi gerak tubuh dilebihkan untuk menyajikan keindahan visual dalam panel relief. Kepekaan dalam mengatur gerak tubuh pada sajian visual relief sejalan dengan teori yang digunakan selama ini dalam pemotretan model khususnya untuk kebutuhan pembuatan iklan fesyen. Munculnya teori-teori yang melandasi pengarahan pose pada pemotretan model dapat ditemukan secara lengkap dalam panel-panel relief Karmawibhangga, yang dalam hal ini sebagai objek utama dalam penelitian.

Kekayaan nilai-nilai estetika yang tekandung di dalam panel relief Karmawibhangga yang berhubungan erat dengan dunia keilmuan fotografi menjadi sesuatu yang menarik untuk dikembangkan lebih jauh lagi, tidak hanya sebatas penggalian pose belaka. Pemanfaatan peninggalan nilai-nilai estetika dari nenek moyang dapat menjadi jalan untuk mempertegas karakter fotografi nusantara. Penelitian ini hanya sebagian kecil dari timbunan peninggalan kekayaan nilai-nilai estetika yang belum tergali dengan baik. 


\section{DAFTAR PUSTAKA}

Hacking, J. (2012). Photography: The Hole Story. London: Theme \& Hudson.

Kandahjaya, H. (1995). The Master Key for Reading Borobudur Symbolism. Jakarta: Karaniya.

Leber, T. (2011). Lalitavistara. Jakarta: KPG.

Prayanto, W. H. (2007). Fotografer dan Riset. ARS: Jurnal Seni Rupa dan Desain, 6(2), 9-17.

Sachari, A. (2007). Budaya Visual Indonesia. Jakarta: Erlangga. 